\title{
Flagged Mutations Present Indicator
}

National Cancer Institute

\section{Source}

National Cancer Institute. Flagged Mutations Present Indicator. NCI Thesaurus. Code C158255.

An indication as to whether the pre-specified mutations of interest are present in the subject. 